\title{
Suggestive Linkage at 9p22 in Bipolar Disorder Weighted by Alcohol Abuse
}

\section{Erika F.H. Saunders, ${ }^{1,2,3 *}$ Peng Zhang, ${ }^{4}$ J. Nathan Copeland, ${ }^{5}$ Melvin G. McInnis, ${ }^{1,2}$ and Sebastian Zöllner ${ }^{1,2,4}$}

\author{
${ }^{1}$ University of Michigan Depression Center, Ann Arbor, Michigan \\ ${ }^{2}$ University of Michigan Department of Psychiatry, Ann Arbor, Michigan \\ ${ }^{3}$ Penn State University College of Medicine Department of Psychiatry, Hershey, Pennsylvania \\ ${ }^{4}$ University of Michigan Department of Biostatistics, Ann Arbor, Michigan \\ ${ }^{5}$ University of Michigan Department of Epidemiology, Ann Arbor, Michigan
}

Received 3 October 2008; Accepted 14 January 2009

Bipolar disorder (BP) is a highly heritable disorder, however attempts to map genetic risk factors are challenging. One possible reason for these difficulties is the genetic heterogeneity of BP. Hence, focusing on clinically homogeneous families to create a genetically more homogeneous sample may increase the power of finding a specific variant. Alcohol abuse (AA) and alcohol dependence (AD) are familial in BP families, and these families may carry a specific risk variant for $B P$. We tested this hypothesis by performing a genome-wide linkage scan in 638 pedigrees $(1,835$ individuals) from the National Institute of Mental Health Genetics Initiative for BP, weighting the evidence for linkage according to the family's frequency of AA or AD. Using AA weighting, we identified a linkage region on 9p22.2 with an NPL score of 3.23. The region had previously been identified in a metaanalysis of linkage in bipolar disorder. We used permutation analysis to assess if weighting by AA increased the linkage signal more than expected by chance and observed a significant $P$-value $(P=0.048)$. Therefore, the genetic risk factor for BP on $9 \mathrm{p} 22.2$ has an increased effect in families with high levels of AA. In summary, we present an example of using covariates such as AA and $A D$ to define subtypes of $B P$, demonstrate how using such subtypes can improve the power of a linkage scan, and demonstrate statistical approaches to validate the suggested interaction. (c) 2009 Wiley-Liss, Inc.

Key words: bipolar disorder; genetics; alcoholism; mood disorder; linkage analysis

Bipolar disorders (BP) are recurrent, episodic disorders of mood characterized by manic or hypomanic and depressive episodes affecting 1-2\% of the population [Merikangas et al., 2007]. BP has concordance rates of $67 \%$ in monozygotic twins and $20 \%$ in dizygotic twins and first-degree relatives [Bertelsen et al., 1977] and an estimated heritability of 59-87\% [Smoller and Finn, 2003]. Linkage studies in BP have had promising, but mixed, results. Three recent meta-analyses of BP linkage studies show evidence for linkage in six different areas: chromosome $9 p$ and $10 q$

\section{How to Cite this Article:}

Saunders EFH, Zhang P, Copeland JN, Mclnnis MG, Zöllner S. 2009. Suggestive Linkage at 9p22 in Bipolar Disorder Weighted by Alcohol Abuse.

Am J Med Genet Part B 150B:1133-1138.

[Segurado et al., 2003], 13q and 22q [Badner and Gershon, 2002], and 6q and 8q [McQueen et al., 2005]. One possible reason for disparate findings in different studies is clinical heterogeneity in the diagnosis of BP [Kelsoe, 2003]. If such clinical heterogeneity is the effect of multiple underlying risk alleles, families will segregate different risk alleles and thus provide conflicting information. Under this model, concentrating the analysis on families that carry a specific variant will increase the power of these studies substantially. One approach to identify such a subset of families is to study linkage in a more clinically homogeneous sample. Recent linkage studies of BP have used this approach with age of onset [Faraone et al., 2004; Lin et al., 2005; Zandi et al., 2007], comorbid anxiety [Zandi et al., 2007], comorbid panic disorder [MacKinnon et al., 1998; Cheng et al., 2006], psychosis [Potash et al., 2003; Cheng et al., 2006; Zandi et al., 2007], and suicidal behavior [Cheng et al., 2006; Willour et al., 2007].

Grant sponsor: Rachel Upjohn Clinical Scholars Program; Grant sponsor: Heinz C. Prechter Pediatric Bipolar Scholars Program; Grant sponsor: Rachel Upjohn Clinical Scholars Award; Grant number: R01 HL090564-01. ${ }^{\star}$ Correspondence to:

Erika F.H. Saunders, Department of Psychiatry, HP16, Penn State Milton S. Hershey Medical Center, Hershey Medical Center, 500 University Drive, P.O. Box 850, Hershey, PA 17033. E-mail: esaunders@hmc.psu.edu Published online 3 March 2009 in Wiley InterScience

(www.interscience.wiley.com)

DOI 10.1002/ajmg.b.30937 
Here we explore BP in comorbidity with alcohol abuse (AA) or alcohol dependence $(\mathrm{AD})$. AA is defined as continued drinking despite social, legal or interpersonal problems; $\mathrm{AD}$ includes physiological tolerance or withdrawal [APA, 2000]. We differentiate between $\mathrm{AA}$ and $\mathrm{AD}$ because the categories describe different patterns of use: AA can occur when an individual uses alcohol in a manner that seriously interferes with their lives. It may be intermittent, for example in a binge-drinking fashion only during manias or represent a persistent maladaptive pattern of over use, for example, frequent but predictable heavy use with notable personal consequences. Alcohol dependence, on the other hand, describes a level of chronic use that results in physiological consequences (e.g., tolerance) with overwhelming psychological cravings and a repertoire of behaviors centered around using alcohol. Furthermore AA and $\mathrm{AD}$ diagnoses describe distinct long-term behavioral patterns; in prospective studies only $3.5 \%$ of AA subjects develop $\mathrm{AD}$ within 5 years, comparable to $2.5 \%$ incidence of $\mathrm{AD}$ in subjects with no alcohol-related diagnosis [Schuckit et al., 2001]. Thus, AA is not simply a "first step" to $\mathrm{AD}$, but a different pattern of drinking that persists over time.

$\mathrm{AA}$ is comorbid with any $\mathrm{BP}$ at a rate of $39.1 \%$; $\mathrm{AD}$ at a rate of 23.2\% [Merikangas et al., 2007], these rates are twice as high as those in the general population [Hasin et al., 2007]. In a prospective cohort study, risk of AA was increased by pre-existing manic symptoms (OR 2.4 (95\% CI 1.2-4.8)), and by a pre-existing diagnosis of BPII (OR 9.1 (95\% CI 27-31.2)). The risk of AD was also increased by pre-existing manic symptoms (OR 4.4 (95\% CI 1.6-12.7)), and by pre-existing BPII (OR 21.1 (95\% CI 6.6-67.5)) [Merikangas et al., 2008]. Clinically, comorbidity of AA/AD with $\mathrm{BP}$ is detrimental to the patient in more ways than the added burden of disease. AA/AD is correlated with higher rates of suicidality [Potash et al., 2000; Baldassano, 2006] and increased number of hospitalizations [Cassidy et al., 2001], a less favorable response to lithium [Goldberg et al., 1999] and rapid-cycling [McKowen et al., 2005].

The genetic predisposition to alcoholism has been hypothesized to constitute part of the genetic predisposition to bipolar disorder and vice versa [Winokur et al., 1996, 1998], and this genetic overlap explains the greater propensity for developing both $\mathrm{BP}$ and $\mathrm{AA} / \mathrm{AD}$. Heritability estimates of AA/AD based on twin studies have been as high as $50-60 \%$ [Prescott, 2001]. Furthermore, we and others found $\mathrm{AA} / \mathrm{AD}$ to be familial in bipolar disorder, indicating that the increased comorbidity may be related to heritable causes [Winokur et al., 1996; Schulze et al., 2006; Nurnberger et al., 2007; Potash et al., 2007; Saunders et al., 2008]. Evidence of heritability for AA/AD and BP, combined with studies of familiality suggest nonlinear interaction of $\mathrm{AA} / \mathrm{AD}$ and genetic risk variants for BP. In this model such risk variants will be more common in families with large number of members with AA/AD. Thus, we expect stronger signals for linkage in families with high levels of $\mathrm{AA}$ or $\mathrm{AD}$. We tested this hypothesis by weighting the evidence for linkage in each family according to the family's frequency of AA or $\mathrm{AD}$. We consider $\mathrm{AA}$ and $\mathrm{AD}$ separately because they describe differing, enduring patterns of drinking behavior that may have different genetic bases. In addition to directly considering the resulting linkage signal we also test whether our weighting scheme significantly improves the evidence for linkage.
We obtained phenotype and genotype data on 711 pedigrees (5,364 individuals) from the National Institute of Mental Health Genetics Initiative for BP. This sample was collected over 15 years at 10 sites across the country. Methods for collection of this sample have been described elsewhere [Dick et al., 2003; McInnis et al., 2003]. Diagnostic assessment was done using the Diagnostic Interview for Genetic Studies [Nurnberger et al., 1994], and psychiatric diagnoses including mood and substance use disorder diagnoses were assigned using a best-estimate process [Leckman et al., 1982]. Within that sample, four disorders were of interest: BPI $(\mathrm{N}=956)$, schizoaffective disorder-bipolar type (SAB) $(\mathrm{N}=72)$, BPII $(\mathrm{N}=128)$, and major depressive disorder-recurrent (MDDR) $(\mathrm{N}=148)$. We classified subjects into three affectation status models. Model 1 included 635 families with subjects affected by SAB or BPI, model 2 included 637 families affected by SAB, BPI, or BPII, and model 3 included 638 families affected by SAB, BPI, BPII, or MDDR.

Information on alcohol use was collected for 1,835 of these persons; $64 \%$ of this subsample were female, and the mean age of interview was 43 . The mean age of onset of BP was significantly reduced in both the $\mathrm{AA}(P=0.006, t$-test $)$ and $\mathrm{AD}\left(P=7.2 \times 10^{-6}\right.$, $t$-test) groups. $\mathrm{AD}$ in $\mathrm{BP}$ families was associated with a smaller likelihood of being currently married $\left(P=1.6 \times 10^{-5}, \chi^{2}\right.$-test, $\left.1 \mathrm{df}\right)$, lower mean number of school years $\left(P=3.0 \times 10^{-7}, \chi^{2}\right.$-test, $\left.1 \mathrm{df}\right)$, lower mean number of children $\left(P=0.009, \chi^{2}\right.$-test, $\left.1 \mathrm{df}\right)$, and more episodes of illness $\left(P=0.015, \chi^{2}\right.$-test, $\left.1 \mathrm{df}\right)$.

Individuals were typed for 391 microsatellite markers with an average spacing of $9 \mathrm{cM}$ and average heterozygosity of 0.76 from a modification of the Cooperative Human Linkage Center version 9 [Dick et al., 2003; McInnis et al., 2003]. We used GENEHUNTERPLUS (GHP) [Kruglyak et al., 1996] to perform multipoint nonparametric linkage analyses using the allele-sharing model (ASM) [Kong and Cox, 1997] analysis found in the GHP package calculating an NPL-score for each locus.

To weight for each pedigree by family levels of AA, we counted the number of individuals with AA in a family regardless of affection status and divided this count by the total number of family members with information known regarding alcohol abuse or dependence. We generated weights for family levels of $\mathrm{AD}$ analogously. Under this weighting scheme, 510 families based on AA and 355 families based on AD had a weight of zero (Fig. 1) and were thus ignored in the linkage analysis.

Using these weights, we recalculated NPL-scores for each family and each locus in the genome. Note that families with a weight of zero do not contribute to the evidence for linkage. To assess the significance of the observed increase in NPL score, we performed permutation studies. In each replication, we randomly reassigned the AA weights to the 711 families. Using the randomized weight file we repeated the ASM analysis and recorded the maximum NPL score. The process was repeated 1,000 times providing an empirical distribution. Comparing this empirical distribution with NPL scores generated using the original AA weighting, we generated $P$-values for these observations. We analogously generated $P$-values for NPL-scores based on AD weights.

Using AA weighting and affection status model 1, we observed a maximum NPL score of 3.23 , with a corresponding LOD of 2.77 . This linkage peak was located on chromosome 9p22.2, at $38.45 \mathrm{cM}$ 

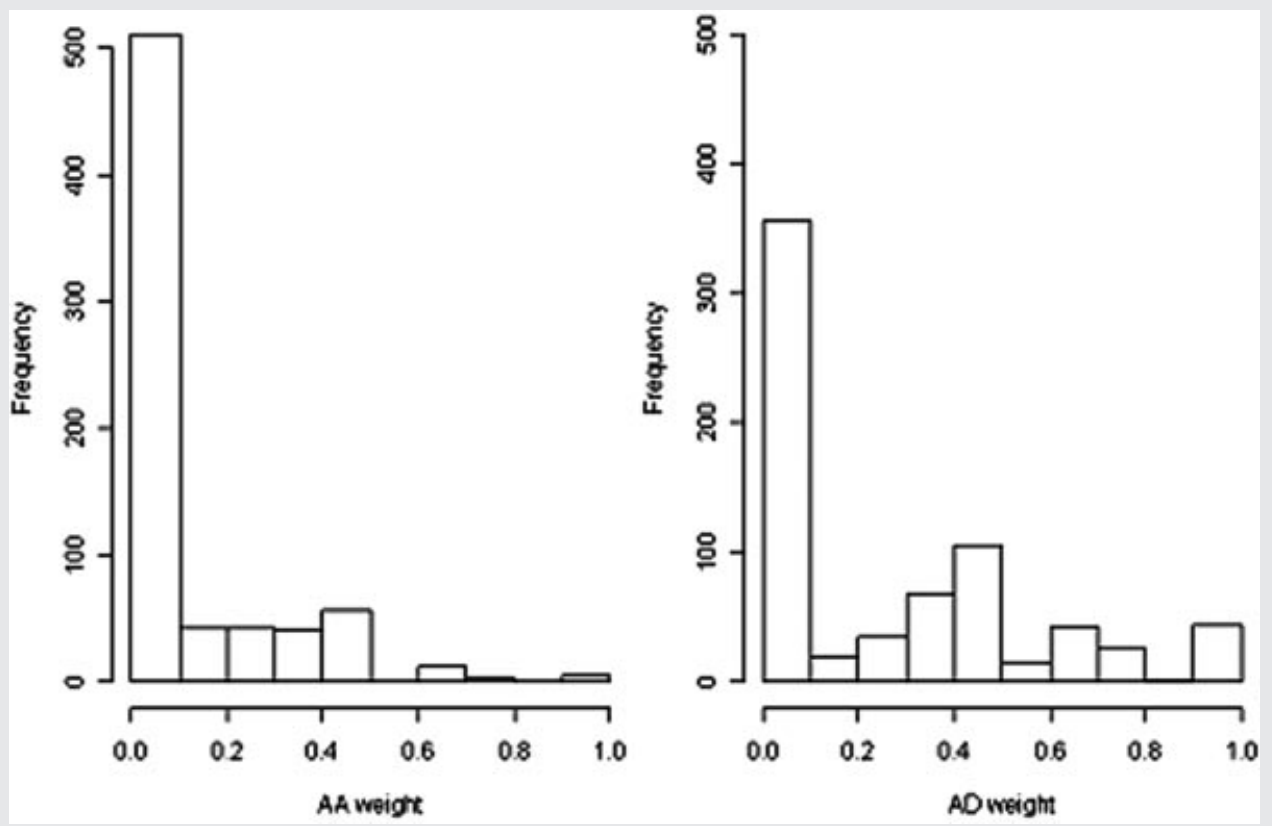

FIG. 1. Number of families with each alcohol abuse [left] or alcohol dependence [right] weight. Weights are a proportion calculated by the number of family members with $A A$ or $A D$ divided by the total number of family members.

marker D9S925 (Fig. 2). This NPL score is a substantive improvement over the NPL-score generated using uniform weights (1.74). Nevertheless, the LOD score does not meet genome-wide significance standard of 3.3; however it is higher than the threshold of 1.9 for suggestive linkage [Lander and Kruglyak, 1995]. Permutation analysis indicated that the improved signal for linkage at 9p22.2 is higher than expected by chance $(P=0.048)$ and thus likely a result of our weighting scheme. The second strongest signal generated using weighting by AA was located on chromosome 3 p14 at $77.12 \mathrm{cM}$, marker D3S4542. The NPL of 2.94 and LOD of 2.53 observed at this locus were above the threshold for suggestive linkage as well. Weighting on $\mathrm{AD}$, we did not observe any regions

\section{Chromosome 9, model 1}

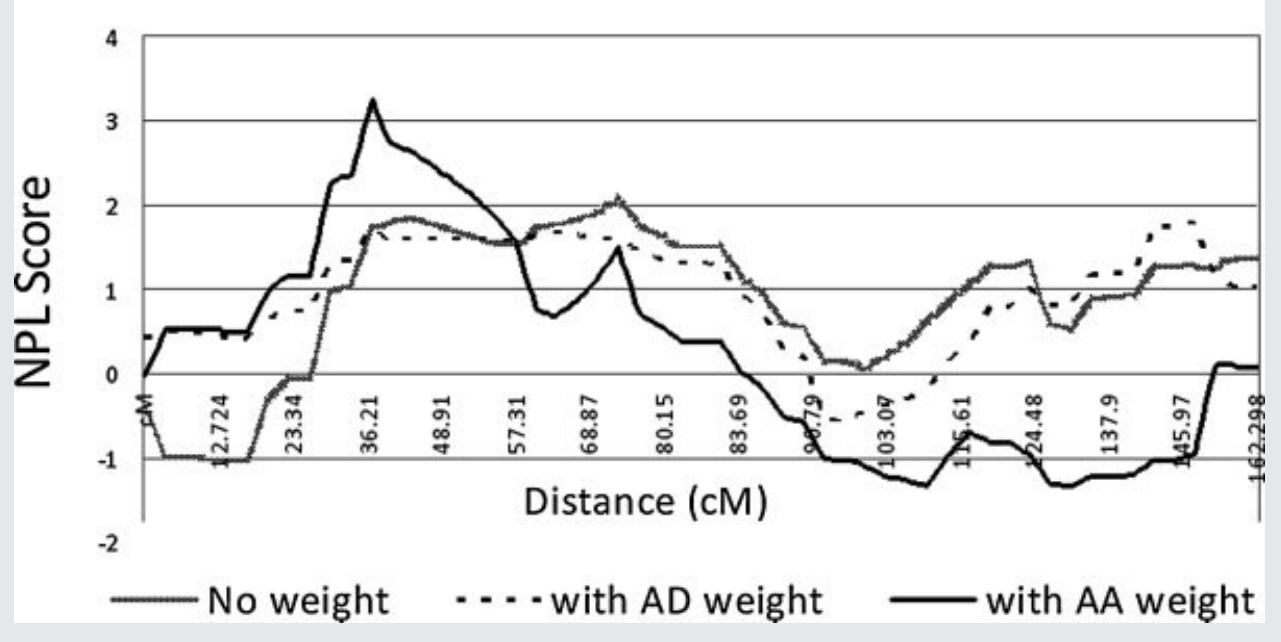

FIG. 2. A suggestive area of linkage at 9p22 (NPL 3.23) with alcohol abuse (AA) weight. This region showed significant difference from the NPL score without weighting or with alcohol dependence $(A D)$ weight. 
with strong linkage. The strongest signal we observed using model 3 affectation status was an NPL score of 2.41 found on chromosome 8 , p23.2 at $4.30 \mathrm{cM}$ with a corresponding LOD of 2.03. The weighting scheme actually decreased the NPL score; the unweighted score was 2.53 .

In summary, we identified a suggestive linkage signal for bipolar disorder on chromosomal region 9p22 after weighting families by frequency of AA. This locus was previously identified as a region of suggestive linkage in bipolar disorder in a recent meta-analysis [Segurado et al., 2003]. This meta-analysis was mostly influenced by two unrelated samples, the Wellcome Trust UK-Irish sample [Bennett et al., 2002], and an unpublished study in Australia. However, further replication is necessary to affirm this finding.

Using permutation, we showed that our weighting scheme significantly enhanced the linkage signal, generating a maximum NPL score that is higher than expected by chance. The statistical significance of the linkage result indicates an increased effect of the detected locus in families with high levels of AA. To further evaluate the nature of this interaction, consider that the weighting scheme included family members with AA regardless of mood disorder. By not restricting the weighting to family members affected by mood disorder, we assumed a risk variant that jointly increases the risk for AA and BP disorder. Such an allele is most likely to segregate in families with large numbers of individuals affected with AA. However, an equally valid interpretation of our results is a risk variant on 9p22 that has a particularly high effect size in a difficult home environment generated by high familial levels of AA. Further investigation is needed to separate these hypotheses.

Remarkably, after weighting for $\mathrm{AD}$, we do not observe any significantly improved linkage signal for BP. This is surprising given the evidence for familiality of $\mathrm{AD}$. In a non-bipolar sample in a study of the genetics of alcoholism, the Collaborative Studies of Genetics of Alcoholism sample, AD but not AA, was demonstrated to be highly familial [Nurnberger et al., 2004]. Several studies of familiality of alcoholism in bipolar samples have not differentiated between AA and AD phenotypes [Winokur et al., 1996; Schulze et al., 2005, 2006; Potash et al., 2008; Saunders et al., 2008]; one study in the NIMH GI dataset revealed that relatives of probands with affective disorders (particularly BPI and SAB) were more likely to have $\mathrm{AD}$, but AA was not studied [Nurnberger et al., 2007]. Given these findings, it is surprising that we detect a signal with $\mathrm{AA}$ weighting and not $\mathrm{AD}$ weighting. While this result may simply be explained by low power of our approach, this seems unlikely as the number of families with nonzero $\mathrm{AD}$ weight is almost twice as high as the number of families with nonzero AA weight. More likely, the interaction between $\mathrm{BP}$ and $\mathrm{AD}$ is not captured by our weighting scheme. We refrained from testing a wider range of weighting schemes, as applying multiple schemes would require adjusting for multiple testing and we are unlikely to have sufficient power to overcome the associated penalty.

If there truly is a risk variant for BP that is present in AA families and not $\mathrm{AD}$ families, it may predispose individuals to impulsive behaviors that then take the form of alcohol abuse during mood episodes. Mood-dependent drinking occurs frequently in BP [reviewed in Goodwin and Jamison, 2007], and is an area of significant concern clinically, as alcohol abuse causes legal and social problems which add to the devastating toll of BP.
$\mathrm{AA}$ and $\mathrm{AD}$ are both potentially useful markers for defining subtypes of BP and exploring their interaction with genetic risk factors may thus further the understanding of its heterogeneity. Hence, the demonstrated interaction between AA and BP may help identifying subtypes of BP and tailor treatment strategies to the patient.

\section{ACKNOWLEDGMENTS}

Data and biomaterials were collected as part of 10 projects that participated in the National Institute of Mental Health (NIMH) Bipolar Disorder Genetics Initiative. From 1999 to 2003, the Principal Investigators and Co-Investigators were: Indiana University, Indianapolis, IN, R01 MH59545, John Nurnberger, M.D., Ph.D., Marvin J. Miller, M.D., Elizabeth S. Bowman, M.D., N. Leela Rau, M.D., P. Ryan Moe, M.D., Nalini Samavedy, M.D., Rif El-Mallakh, M.D. (at University of Louisville), Husseini Manji, M.D. (at Wayne State University), Debra A. Glitz, M.D. (at Wayne State University), Eric T. Meyer, M.S., Carrie Smiley, R.N., Tatiana Foroud, Ph.D., Leah Flury, M.S., Danielle M. Dick, Ph.D., Howard Edenberg, Ph.D.; Washington University, St. Louis, MO, R01 MH059534, John Rice, Ph.D., Theodore Reich, M.D., Allison Goate, Ph.D., Laura Bierut, M.D.; Johns Hopkins University, Baltimore, MD, R01 MH59533, Melvin McInnis M.D., J. Raymond DePaulo, Jr., M.D., Dean F. MacKinnon, M.D., Francis M. Mondimore, M.D., James B. Potash, M.D., Peter P. Zandi, Ph.D., Dimitrios Avramopoulos, and Jennifer Payne; University of Pennsylvania, PA, R01 MH59553, Wade Berrettini M.D., Ph.D.; University of California at Irvine, CA, R01 MH60068, William Byerley M.D., and Mark Vawter M.D.; University of Iowa, IA, R01 MH059548, William Coryell M.D., and Raymond Crowe M.D.; University of Chicago, IL, R01 MH59535, Elliot Gershon, M.D., Judith Badner Ph.D., Francis McMahon M.D., Chunyu Liu Ph.D., Alan Sanders M.D., Maria Caserta, Steven Dinwiddie M.D., Tu Nguyen, Donna Harakal; University of California at San Diego, CA, R01 MH59567, John Kelsoe, M.D., Rebecca McKinney, B.A.; Rush University, IL, R01 MH059556, William Scheftner M.D., Howard M. Kravitz, D.O., M.P.H., Diana Marta, B.S., Annette Vaughn-Brown, MSN, RN, and Laurie Bederow, MA; NIMH Intramural Research Program, Bethesda, MD, 1Z01MH00281001, Francis J. McMahon, M.D., Layla Kassem, PsyD, Sevilla DeteraWadleigh, Ph.D., Lisa Austin, Ph.D., Dennis L. Murphy, M.D. Most importantly, we thank the families who have participated in and contributed to these studies. E.F.H.S. was supported by the Rachel Upjohn Clinical Scholars Program and the Heinz C. Prechter Pediatric Bipolar Scholars Program. S.Z. is supported by a Rachel Upjohn Clinical Scholars Award and R01 HL090564-01.

\section{REFERENCES}

APA. 2000. Diagnostic and statistical manual of mental disorders: DSM-IV-TR. Washington, DC:American Psychiatric Association. p 943.

Badner JA, Gershon ES. 2002. Meta-analysis of whole-genome linkage scans of bipolar disorder and schizophrenia. Mol Psychiatry 7:405-411.

Baldassano CF. 2006. Illness course, comorbidity, gender, and suicidality in patients with bipolar disorder. J Clin Psychiatry 67(Suppl11): 8-11. 
Bennett P, Segurado R, Jones I, Bort S, McCandless F, Lambert D, Heron J, Comerford C, Middle F, Corvin A, Pelios G, Kirov G, Larsen B, Mulcahy T, Williams N, O'Connell R, O'Mahony E, Payne A, Owen M, Holmans P, Craddock N, Gill M. 2002. The Wellcome trust UK-Irish bipolar affective disorder sibling-pair genome screen: First stage report. Mol Psychiatry 7:189-200.

Bertelsen A, Harvald B, Hauge M. 1977. A Danish twin study of manicdepressive disorders. Br J Psychiatry 130:330-351.

Cassidy F, Ahearn EP, Carroll BJ. 2001. Substance abuse in bipolar disorder. Bipolar Disord 3:181-188.

Cheng R, Juo SH, Loth JE, Nee J, Iossifov I, Blumenthal R, Sharpe L, Kanyas K, Lerer B, Lilliston B, Smith M, Trautman K, Gilliam TC, Endicott J, Baron M. 2006. Genome-wide linkage scan in a large bipolar disorder sample from the national institute of mental health genetics initiative suggests putative loci for bipolar disorder, psychosis, suicide, and panic disorder. Mol Psychiatry 11:252-260.

Dick DM, Foroud T, Flury L, Bowman ES, Miller MJ, Rau NL, Moe PR, Samavedy N, El-Mallakh R, Manji H, Glitz DA, Meyer ET, Smiley C, Hahn R, Widmark C, McKinney R, Sutton L, Ballas C, Grice D, Berrettini W, Byerley W, Coryell W, DePaulo R, MacKinnon DF, Gershon ES, Kelsoe JR, McMahon FJ, McInnis M, Murphy DL, Reich T, Scheftner W, Nurnberger JI Jr. 2003. Genomewide linkage analyses of bipolar disorder: A new sample of 250 pedigrees from the national institute of mental health genetics initiative. Am J Hum Genet 73:107-114.

Faraone SV, Glatt SJ, Su J, Tsuang MT. 2004. Three potential susceptibility loci shown by a genome-wide scan for regions influencing the age at onset of mania. Am J Psychiatry 161:625-630.

Goldberg JF, Garno JL, Leon AC, Kocsis JH, Portera L. 1999. A history of substance abuse complicates remission from acute mania in bipolar disorder. J Clin Psychiatry 60:733-740.

Goodwin FK, Jamison KR. 2007. Manic-depressive illness: Bipolar disorders and recurrent depression. New York, NY:Oxford University Press. p 1262.

Hasin DS, Stinson FS, Ogburn E, Grant BF. 2007. Prevalence, correlates, disability, and comorbidity of DSM-IV alcohol abuse and dependence in the United States: Results from the national epidemiologic survey on alcohol and related conditions. Arch Gen Psychiatry 64:830-842.

Kelsoe JR. 2003. Arguments for the genetic basis of the bipolar spectrum. J Affect Disord 73:183-197.

Kong A, Cox NJ. 1997. Allele-sharing models: LOD scores and accurate linkage tests. Am J Hum Genet 61:1179-1188.

Kruglyak L, Daly MJ, Reeve-Daly MP, Lander ES. 1996. Parametric and nonparametric linkage analysis: A unified multipoint approach. Am J Hum Genet 58:1347-1363.

Lander E, Kruglyak L. 1995. Genetic dissection of complex traits: Guidelines for interpreting and reporting linkage results. Nat Genet 11:241-247.

Leckman JF, Sholomskas D, Thompson WD, Belanger A, Weissman MM. 1982. Best estimate of lifetime psychiatric diagnosis: A methodological study. Arch Gen Psychiatry 39:879-883.

Lin PI, McInnis MG, Potash JB, Willour VL, Mackinnon DF, Miao K, Depaulo JR, Zandi PP. 2005. Assessment of the effect of age at onset on linkage to bipolar disorder: Evidence on chromosomes 18p and 21q. Am J Hum Genet 77:545-555.

MacKinnon DF, Xu J, McMahon FJ, Simpson SG, Stine OC, McInnis MG, DePaulo JR. 1998. Bipolar disorder and panic disorder in families: An analysis of chromosome 18 data. Am J Psychiatry 155:829-831.
McInnis MG, Dick DM, Willour VL, Avramopoulos D, MacKinnon DF, Simpson SG, Potash JB, Edenberg HJ, Bowman ES, McMahon FJ, Smiley C, Chellis JL, Huo Y, Diggs T, Meyer ET, Miller M, Matteini AT, Rau NL, DePaulo JR, Gershon ES, Badner JA, Rice JP, Goate AM, DeteraWadleigh SD, Nurnberger JI, Reich T, Zandi PP, Foroud TM. 2003. Genome-wide scan and conditional analysis in bipolar disorder: Evidence for genomic interaction in the national institute of mental health genetics initiative bipolar pedigrees. Biol Psychiatry 54:1265-1273.

McKowen JW, Frye MA, Altshuler LL, Gitlin MJ. 2005. Patterns of alcohol consumption in bipolar patients comorbid for alcohol abuse or dependence. Bipolar Disord 7:377-381.

McQueen MB, Devlin B, Faraone SV, Nimgaonkar VL, Sklar P, Smoller JW, Abou Jamra R, Albus M, Bacanu SA, Baron M, Barrett TB, Berrettini W, Blacker D, Byerley W, Cichon S, Coryell W, Craddock N, Daly MJ, Depaulo JR, Edenberg HJ, Foroud T, Gill M, Gilliam TC, Hamshere M, Jones I, Jones L, Juo SH, Kelsoe JR, Lambert D, Lange C, Lerer B, Liu J, Maier W, Mackinnon JD, McInnis MG, McMahon FJ, Murphy DL, Nothen MM, Nurnberger JI, Pato CN, Pato MT, Potash JB, Propping P, Pulver AE, Rice JP, Rietschel M, Scheftner W, Schumacher J, Segurado R, Van Steen K, Xie W, Zandi PP, Laird NM. 2005. Combined analysis from eleven linkage studies of bipolar disorder provides strong evidence of susceptibility loci on chromosomes $6 \mathrm{q}$ and $8 \mathrm{q}$. Am J Hum Genet 77:582-595.

Merikangas KR, Akiskal HS, Angst J, Greenberg PE, Hirschfeld RM, Petukhova M, Kessler RC. 2007. Lifetime and 12-month prevalence of bipolar spectrum disorder in the national comorbidity survey replication. Arch Gen Psychiatry 64:543-552.

Merikangas KR, Herrell R, Swendsen J, Rossler W, Ajdacic-Gross V, Angst J. 2008. Specificity of bipolar spectrum conditions in the comorbidity of mood and substance use disorders: Results from the Zurich cohort study. Arch Gen Psychiatry 65:47-52.

Nurnberger JI Jr, Blehar MC, Kaufmann CA, York-Cooler C, Simpson SG, Harkavy-Friedman J, Severe JB, Malaspina D, Reich T. 1994. Diagnostic interview for genetic studies. rationale, unique features, and training. NIMH genetics initiative. Arch Gen Psychiatry 51:849-859; discussion 863-4.

Nurnberger JI Jr, Wiegand R, Bucholz K, O’Connor S, Meyer ET, Reich T, Rice J, Schuckit M, King L, Petti T, Bierut L, Hinrichs AL, Kuperman S, Hesselbrock V, Porjesz B. 2004. A family study of alcohol dependence: Coaggregation of multiple disorders in relatives of alcohol-dependent probands. Arch Gen Psychiatry 61:1246-1256.

Nurnberger JI Jr, Kuperman S, Flury-Wetherill L, Meyer ET, Lawson WB, Mackinnon DF. 2007. Genetics of comorbid mood disorder and alcohol dependence. J Dual Diagnosis 3:31-46.

Potash JB, Kane HS, Chiu YF, Simpson SG, MacKinnon DF, McInnis MG, McMahon FJ, DePaulo JR Jr. 2000. Attempted suicide and alcoholism in bipolar disorder: Clinical and familial relationships. Am J Psychiatry 157:2048-2050.

Potash JB, Zandi PP, Willour VL, Lan TH, Huo Y, Avramopoulos D, Shugart YY, MacKinnon DF, Simpson SG, McMahon FJ, DePaulo JR Jr, McInnis MG. 2003. Suggestive linkage to chromosomal regions 13q31 and 22q12 in families with psychotic bipolar disorder. Am J Psychiatry 160:680-686.

Potash JB, Toolan J, Steele J, Miller EB, Pearl J, Zandi PP, Schulze TG, Kassem L, Simpson SG, Lopez V, MacKinnon DF, McMahon FJ. 2007. The bipolar disorder phenome database: A resource for genetic studies. Am J Psychiatry 164:1229-1237.

Potash JB, Buervenich S, Cox NJ, Zandi PP, Akula N, Steele J, Rathe JA, Avramopoulos D, Detera-Wadleigh SD, Gershon ES, DePaulo JR Jr, Feinberg AP, McMahon FJ. 2008. Gene-based SNP mapping of a psychotic bipolar affective disorder linkage region on 22q12.3: Association with HMG2L1 and TOM1. Am J Med Genet Part B 147B:59-67. 
Prescott CA. 2001. The genetic epidemiology of alcoholism: Sex differences and future directions. In: Agarwal DP SH, editor. Alcohol in health and disease. New York and Basel:Marcel Dekker, Inc. pp 125-149.

Saunders EH, Scott LJ, McInnis MG, Burmeister M. 2008. Familiality and diagnostic patterns of subphenotypes in the national institutes of mental health bipolar sample. Am J Med Genet Part B 147B:18-26.

Schuckit MA, Smith TL, Danko GP, Bucholz KK, Reich T, Bierut L. 2001. Five-year clinical course associated with DSM-IV alcohol abuse or dependence in a large group of men and women. Am J Psychiatry 158:1084-1090.

Schulze TG, Ohlraun S, Czerski PM, Schumacher J, Kassem L, Deschner M, Gross M, Tullius M, Heidmann V, Kovalenko S, Jamra RA, Becker T, Leszczynska-Rodziewicz A, Hauser J, Illig T, Klopp N, Wellek S, Cichon S, Henn FA, McMahon FJ, Maier W, Propping P, Nothen MM, Rietschel M. 2005. Genotype-phenotype studies in bipolar disorder showing association between the DAOA/G30 locus and persecutory delusions: A first step toward a molecular genetic classification of psychiatric phenotypes. Am J Psychiatry 162:2101-2108.

Schulze T, Hedeker D, Zandi P, Rietschel M, McMahon F. 2006. What is familial about familial bipolar disorder? Resemblance among relatives across a broad spectrum of phenotypic characteristics. Arch Gen Psychiatry 63:1368-1376.

Segurado R, Detera-Wadleigh SD, Levinson DF, Lewis CM, Gill M, Nurnberger JI Jr, Craddock N, DePaulo JR, Baron M, Gershon ES, Ekholm J, Cichon S, Turecki G, Claes S, Kelsoe JR, Schofield PR, Badenhop RF, Morissette J, Coon H, Blackwood D, McInnes LA, Foroud T, Edenberg HJ, Reich T, Rice JP, Goate A, McInnis MG, McMahon FJ, Badner JA, Goldin LR, Bennett P, Willour VL, Zandi PP,
Liu J, Gilliam C, Juo SH, Berrettini WH, Yoshikawa T, Peltonen L Lonnqvist J, Nothen MM, Schumacher J, Windemuth C, Rietschel M, Propping P, Maier W, Alda M, Grof P, Rouleau GA, Del-Favero J, Van Broeckhoven C, Mendlewicz J, Adolfsson R, Spence MA, Luebbert H, Adams LJ, Donald JA, Mitchell PB, Barden N, Shink E, Byerley W, Muir W, Visscher PM, Macgregor S, Gurling H, Kalsi G, McQuillin A, Escamilla MA, Reus VI, Leon P, Freimer NB, Ewald H, Kruse TA, Mors O, Radhakrishna U, Blouin JL, Antonarakis SE, Akarsu N. 2003. Genome scan meta-analysis of schizophrenia and bipolar disorder. Part III. Bipolar disorder. Am J Hum Genet 73:49-62.

Smoller JW, Finn CT. 2003. Family, twin, and adoption studies of bipolar disorder. Am J Med Genet Part C 123C:48-58.

Willour VL, Zandi PP, Badner JA, Steele J, Miao K, Lopez V, MacKinnon DF, Mondimore FM, Schweizer B, McInnis MG, Miller EB, Depaulo JR Jr, Gershon ES, McMahon FJ, Potash JB. 2007. Attempted suicide in bipolar disorder pedigrees: Evidence for linkage to 2p12. Biol Psychiatry 61:725-727.

Winokur G, Coryell W, Endicott J, Keller M, Akiskal H, Solomon D. 1996. Familial alcoholism in manic-depressive (bipolar) disease. Am J Med Genet 67:197-201.

Winokur G, Turvey C, Akiskal H, Coryell W, Solomon D, Leon A, Mueller T, Endicott J, Maser J, Keller M. 1998. Alcoholism and drug abuse in three groups-Bipolar I, unipolars and their acquaintances. J Affect Disord 50:81-89.

Zandi PP, Badner JA, Steele J, Willour VL, Miao K, MacKinnon DF, Mondimore FM, Schweizer B, McInnis MG, DePaulo JR Jr, Gershon E, McMahon FJ, Potash JB. 2007. Genome-wide linkage scan of 98 bipolar pedigrees and analysis of clinical covariates. Mol Psychiatry 12:630-639. 